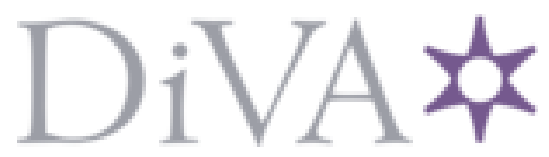

http://www.diva-portal.org

This is the published version of a paper published in Vård $i$ Norden.

Citation for the original published paper (version of record):

Holst, G., Willman, A., Fagerström, C., Borg, C., Hellström, Y. et al. (2010)

Quality of care: prevention of pressure ulcers - nursing students as facilitators of evidence based practice.

Vård i Norden, 30(1): 40-42

Access to the published version may require subscription.

N.B. When citing this work, cite the original published paper.

Permanent link to this version:

http://urn.kb.se/resolve?urn=urn:nbn:se:lnu:diva-41015 


\title{
Quality of care: Prevention of pressure ulcers - Nursing students facilitating evidence-based practice
}

\author{
Göran Holst PhD RN - Ania Willman PhD RN Prof - Cecilia Fagerström PhD RN - Christel Borg PhD RN - Ylva Hellström PhD RN \\ - Gunilla Borglin PhD RN
}

\begin{abstract}
This development project was aimed at engaging nursing students in a project targeting the prevention and reduction of pressure ulcers on an education based hospital ward. An intervention was implemented based on systematic assessment, skin observation, together with training and educational sessions, i.e. on how to make risk assessments and how to prevent and treat a pressure ulcer, were carried out. The project demonstrated the importance of offering nursing students an environment for clinical practice which supports them in participating and developing patient care starting from Evidence-Based Practice. During the project no patients developed pressure ulcers while on the ward. The opportunity to act as facilitators of evidence-based methods was found to enhance student ability to draw conclusions and make connections between quality of care and end result.
\end{abstract}

KEY WORDS: Nursing education, Evidence-Based Practice, Pressure Ulcer, Quality Improvement

\section{Introduction}

Evidence-Based Practice (EBP) has expanded into one of the most important underlying principles in modern healthcare [1]. EBP originates from rapid changes in the delivery of healthcare accompanied by an increased emphasis on quality of care and cost containment [2]. The need to use robust research findings effectively is thus a critical factor for any health service. However, knowledge about how to implement evidenced findings in order to facilitate most effectively practice is still limited [3]. Acquisition of evidence and an aptitude in interpreting research findings are some of the barriers that interfere with the ability of healthcare professionals to implement EBP [2] apart from factors relating to the social and organizational contexts [4]. Thus, there is a need to stimulate the implementation of EBP in clinical practice using different approaches.

In Sweden, the education in clinical practice within the nursing programmes aims to motivate the students to adopt a scientific approach to their future profession. Swedish educational regulations (HSV 2007:23 R) emphasise the equal importance of theoretical studies and clinically-based educational training, and that both components need to achieve the same high quality. The same demands are made on the clinically-based teachers, lecturers, and the clinical supervisors regarding their scientific and pedagogical competence. Consequently, the education regarding clinical practice aims to equip the students with academic training in such skills as patient safety, critical and active participation in the development of nursing care and continuous professional and evidence-based development within the discipline. This poses several organisational challenges. The first concerns the creation of an environment that promotes academic learning, whilst the second concerns training students in systematic and evidence-based methods.

Pressure ulcers are a common problem in hospital populations with studies finding a prevalence of around 18\% [5]. However, systematic work taking its point of departure in evidence-based methods [6] can reduce the prevalence of pressure ulcers, and thereby also costs, resource utilisation and patient suffering [7-9]. Factors such as high age, immobility, incontinence, cognitive impairment and low serum albumin are associated with the prevalence of pressure ulcerations within hospital populations [5, 10]. In Europe the work on developing guiding principles for pressure ulcer prevention has been led by the European Pressure Ulcer Advisory Panel (EPUAP), which has contributed to a reduction of pressure ulcers in several areas. Despite this, research indicates difficulties concerning both distribution of new knowledge to professionals and the incorporation of this new knowledge into everyday practice [11]. One solution could be to target nursing students, and equip them with the skills needed to function as evidence-based facilitators.

The teaching team at one small university in southern Sweden decided to support the development of specific education-based hospital wards. Apart from aiming to meet regulatory educational obligations, to a high standard, the initiative was also intended to facilitate the introduction of evidence-based methods into nursing care.

\section{Aim and rationale}

By involving the students, together with the clinical supervisors and ward staff, in a development project targeting an important care problem e.g. the prevention and reduction of pressure ulcers, it was hypothesised that the nursing students would aqquire academic and practical skills and patient safety and the quality of the pressure ulcer nursing care would improve. The development project started out from the theoretical framework the Promoting Action on Research Implementation in Health Services framework - PARIS-which describes how the use of facilitators, in our case the nursing students and clinical teachers, can be a vital factor in quality development [12].

\section{The development project - setting and context}

The development project started during spring 2008 and was preceded by project meetings aimed at inventoring nursing care areas to benchmark, develop and assure quality. Second and third year nursing students, clinical supervisors, ward sister, clinical teachers and lecturers participated in these meetings. A decision was taken to developed interventions targeting pressure ulcers. It was also decided that the clinical teachers and the students doing their clinical practice during the spring semester 2008 would take the lead by starting up the project. The clinical supervisors would be engaged in supporting the students as the project was rolled out. After a review of the literature and based on the findings presented it was decided to include the following actions in the intervention i) systematic risk assessment [13] ii) systematic skin observations [14] and iii) $2 \times 4$ hours training and education sessions (Figure 1).

\section{Intervention Phase I}

Between April and May 2008 the first group of students, with the support from their clinical supervisors, executed the first mapping exercise. The mapping exercise included: systematic assessments of risk 
Figure 1. Overview of intervention components.

\begin{tabular}{|c|c|c|}
\hline $\begin{array}{l}\text { Intervention } \\
\text { Components }\end{array}$ & Assessments & Guidelines \\
\hline $\begin{array}{l}\text { Systematic Risk } \\
\text { assessment }\end{array}$ & Modified Norton scale & $\begin{array}{l}\text { On admission and every fourth day } \\
\text { Modified Norton Screening according to } \\
\text { the criteria: } \\
\text { - Patients } 70 \text { years and older } \\
\text { - Bedridden patients } \\
\text { - Patients in wheelchairs }\end{array}$ \\
\hline $\begin{array}{l}\text { Systematic skin } \\
\text { observations }\end{array}$ & $\begin{array}{l}\text { EPUAP-protocol } \\
\text { Grade 1/ Non-blanchable erythema of intact } \\
\text { skin. Discolouration of the skin. } \\
\text { Grade 2/ Partial thickness skin loss involving } \\
\text { epidermis, dermis or both. } \\
\text { Grade 3/ Full thickness skin loss involving } \\
\text { damage to or necrosis of subcutaneous tissue. } \\
\text { Grade 4/ Extensive destruction, tissue necrosis } \\
\text { or damage. }\end{array}$ & $\begin{array}{l}\text { On admission and, if pressure ulceration } \\
\text { presents, daily inspections. If no pressure } \\
\text { ulceration present every fourth day. }\end{array}$ \\
\hline \multirow[t]{2}{*}{$\begin{array}{l}\text { Pressure Ulcer } \\
\text { Documentation }\end{array}$} & & $\begin{array}{l}\text { - Age } \\
\text { - Gender } \\
\text { - Number of hospital days } \\
\text { - Modified Norton score } \\
\text { - EPUAP score } \\
\text { - Nursing care targeting pressure } \\
\text { ulcerations }\end{array}$ \\
\hline & Target group & Content \\
\hline $\begin{array}{l}\text { Training sessions } \\
2 \times 4 \text { hours } \\
\text { (Trusts Tissue } \\
\text { Viability Centre) }\end{array}$ & $\begin{array}{l}\text { Nursing students } \\
\text { Clinical Supervisors }\end{array}$ & $\begin{array}{l}\text { How to make risk assessment and skin } \\
\text { observation, and how to prevent and care } \\
\text { for a pressure ulcer }\end{array}$ \\
\hline
\end{tabular}

for pressure ulcers, systematic grading of current pressure ulcers and prevalence of pressure ulcers at time of admission and during hospital stay (Figure 1). During this phase students and clinical supervisors also participated in the first education and training session held by specialist nurses from the Trusts Tissue Viability Centre (TVC).

\section{Intervention Phase II}

During autumn 2008 the clinical teachers, lecturers and the supervisor analysed the findings from the mapping exercise carried out in phase I. Discussions were also held concerning potential nursing interventions targeting prevention of pressure ulcers, such as more systematic support for bedridden and incapacitated patients to change positions, increased support for activation, and more systematic skin observations. At this point in time (September 2008) the second education and training session, by Trusts TVC staff also took place. This session targeted the students doing their clinical training during the autumn semester 2008 and for the majority of clinical supervisors this was their second attandence. A second mapping exercise was executed by the new group of students between October and November 2008.

Data collection and data analysis

An intervention sheet containing data concerning age, gender, number of hospital days, Modified Norton score, skin observation, having or not having a pressure ulcer on admission and discharge and nursing interventions was developed by teachers and students jointly.
The intervention sheet was kept with the ordinary patient documentation during the patient's time on the education-based ward. This procedure ensured that all participants remained anonymous for the senior

\begin{tabular}{|c|c|c|c|c|}
\hline & \multicolumn{2}{|c|}{$\begin{array}{l}\text { Phase } I \text { - Spring } 2008 \\
\qquad(\mathrm{n}=35)\end{array}$} & \multicolumn{2}{|c|}{$\begin{array}{l}\text { Phase } I I \text { - Autumn } 2008 \\
\qquad(\mathrm{n}=19)\end{array}$} \\
\hline & $\begin{array}{l}\text { Male } \\
(\mathrm{n}=17)\end{array}$ & $\begin{array}{l}\text { Female } \\
(n=18)\end{array}$ & $\begin{array}{l}\text { Male } \\
(n=10)\end{array}$ & $\begin{array}{l}\text { Female } \\
(\mathrm{n}=9)\end{array}$ \\
\hline Age, mean $(\min -\max )$ & $82(52-101)$ & $82(68-96)$ & $75(62-84)$ & $79(62-96)$ \\
\hline Care days, mean $(\min -\max )$ & $9(2-26)$ & $8(3-23)$ & $9(4-22)$ & $11(3-30)$ \\
\hline \multicolumn{5}{|l|}{ Risk assessment* } \\
\hline $\begin{array}{l}\text { At risk of developing pressure } \\
\text { ulcer }\end{array}$ & 11 & 11 & 8 & 7 \\
\hline $\begin{array}{l}\text { Skin observation** } \\
\text { Pressure Ulcer on admission } \\
\text { assessment }\end{array}$ & 6 & 6 & 5 & 4 \\
\hline $\begin{array}{l}\text { Developed pressure ulcer } \\
\text { during hospital stay }\end{array}$ & 3 & 2 & - & - \\
\hline \multicolumn{5}{|l|}{$\begin{array}{l}\text { Degree of pressure ulcer } \\
\text { developed during hospital } \\
\text { stay }\end{array}$} \\
\hline 1 & 2 & 1 & - & - \\
\hline 2 & 1 & 1 & - & - \\
\hline \multicolumn{5}{|l|}{ Nursing intervention } \\
\hline Care intervention described $* * *$ & 12 & 14 & 9 & 9 \\
\hline $\begin{array}{l}\text { No specific care intervention } \\
\text { described }\end{array}$ & 5 & 4 & - & - \\
\hline
\end{tabular}

Note: $*[13] * *[14] * * *$ Example; decubitus mattresses, softening skin, more frequent positioning 
lecturer $(\mathrm{GH})$ responsible for the data input (SPSS 16.0 for windows) and analysis.

\section{Findings}

The students planned and executed most of the nursing care that targeted pressure ulcers during the two phases of the project. The students' role came to be valued and was viewed as a complement to the nursing care on the ward. Anecdotally, both staff and students reflected on what the project had achieved and the ward sister stated at one meeting:

"We have always tried hard to prevent pressure ulcers, but this project has opened our eyes of its importance and the nursing students have now been a valuable asset in this work».

\section{Intervention phase I}

A total of 35 patients (18 females) were included. Their mean stay on the ward was approximately about 8-9 days. In accordance to the systematic assessments using the Modified Norton scale, about $60 \%$ of the patients were at risk of developing pressure ulceration. Mapping exercise I showed that about half of the patients had pressure ulcerations during the time they were cared for. Every third patient arrived on the ward with pressure ulceration and every tenth patient developed some degree of pressure ulceration during their stay. Documentation showed that the most common nursing care interventions were to use decubitus mattresses, some form of skin softening, de-pressuring and more frequent positioning (Table 1).

\section{Intervention phase II}

The second mapping exercise included 19 patients. These were younger than the patients in phase I, but despite this about $79 \%$ were within the risk zone of developing pressure ulceration, according to the Modified Norton scale. Eight patients arrived on the ward with pressure ulcers and still had them when discharged. During this phase no patient developed pressure ulcers and more preventive nursing care interventions were documented (Table 1).

\section{Discussion}

Our conclusion after this development project is that it is well worth supporting the continuous development of education-based hospital wards. Being able to offer nursing students a clinical practice environment that supports thir participating in and development of patient care, starting from EBP was found to give them the opportunity to draw conclusions and make connections between the quality of care and an end result [15]. We can also conclude that patient safety and quality of care improved i.e. no patients in phase II developed pressure ulcers during their stay, in comparison with five patients in phase I.

It is important, however, to note that this development project took place in a clinical setting and was not therefore, set up with the methodological rigor inherent a research project. It is also important to remember that the patients in phase II were slightly younger, particularly as research has shown that advanced age is one of the risk factors for developing pressure ulcerations $[1,6]$. Furthermore, the project included only a small number of patients, and particular the number of patients included in phase II was smaller than in phase I. All these points need to be taken into account when evaluating this project. Nevertheless, it appears reasonable to assume that one of the reasons no pressure ulcers developed during phase II can be related to the interventions that took place on the ward. Thus, the findings indicate that even relatively simple small-scale interventions can have the possibility of influencing the quality of nursing care when the interventions target one specific problem area. The findings of other research studies also support our suggestion [7].

\section{Acknowledgements}

The authors wish to thank Agneta Lindwall, Clinical teacher, clinical supervisors and nursing students at the education-based ward for their participation in the study and to Ms Patricia Shrimpton for revising the English.

Göran Holst PhD RN, Ania Willman PhD RN Prof, Cecilia Fagerström PhD RN, Christel Borg PhD RN, Ylva Hellström PhD RN, Gunilla Borglin PhD RN

School of Health Sciences, Blekinge Institute of Technology, Blekinge, Sweden

Contact: Goran.Holst@bth.se

\section{References}

1. McKenna, H., Ashton S. and Keeney S., Barriers to evidence-based practice in primary care: a review of the literature. International Journal of Nursing Studies, 2004. 41(4): p. 369-378.

2. Ciliska, D., DiCenso A. and Cullum N., Centres of evidence-based nursing: directions and challenges. Evidence-Based Nursing, 1999(2): p. 102-04.

3. Grol, R., Implementation of evidence and guidelines in clinical practice: a new field of research? International Journal for Quality in Health Care: Journal of The International Society for Quality in Health Care / Isqua, 2000. 12(6): p. 455-456.

4. Grol, R., Between evidence-based practice and total quality management: the implementation of cost-effective care. International Journal for Quality in Health Care: Journal of The International Society for Quality in Health Care / Isqua, 2000. 12(4): p. 297-304.

5. Gallagher, P., et al., Prevalence of pressure ulcers in three university teaching hospitals in Ireland. Journal of Tissue Viability, 2008. 17(4): p. 103-109.

6. Chaboyer, W., et al., Embedding evidence-based practice in a nursing curriculum: a benchmarking project. Nurse Education in Practice, 2004. 4(3): p. 216-223.

7. Gunningberg, L., et al., Reduced incidence of pressure ulcers in patients with hip fractures: a 2-year follow-up of quality indicators. International Journal for Quality in Health Care: Journal of The International Society for Quality in Health Care / Isqua, 2001. 13(5): p. 399-407.

8. Comfort, E.H., Reducing pressure ulcer incidence through Braden Scale risk assessment and support surface use. Advances in Skin \& Wound Care, 2008. 21(7): p. 330-334.

9. Chicano, S.G. and Drolshagen C., Reducing hospital-acquired pressure ulcers. Journal Of Wound, Ostomy, And Continence Nursing: Official Publication Of The Wound, Ostomy And Continence Nurses Society / WOCN, 2009. 36(1): p. 45-50.

10. Wann-Hansson, C., Hagell P., and Willman A., Risk factors and prevention among patients with hospital-acquired and pre-existing pressure ulcers in an acute care hospital. Journal of Clinical Nursing, 2008. 17(13): p. 1718-1727.

11. Wilborn, D., Halfens R., and. Dassen T, Pressure ulcer: Prevention protocols and prevalence. Journal of Evaluation in Clinical Practice, 2006. 12(6): p. 630-638.

12. Kitson, A., Harvey G., and McCormack B., Enabling the implementation of evidence based practice: a conceptual framework. Quality in Health Care: QHC, 1998. 7(3): p. 149-158.

13. Berglund, B. and Nordström G., The use of the Modified Norton Scale in nursing-home patients. Scandinavian Journal of Caring Sciences, 1995. 9(3): p. 165-169.

14. Beeckman, D., et al., EPUAP classification system for pressure ulcers: European reliability study. Journal of Advanced Nursing, 2007. 60(6): p. 682-691.

15. Biggs, J. and Collis K., Evaluating the Quality of Learning: The SOLO Taxonomy (structure of the Observed Learning Outcome). 1982: Academic Press. 